Pleione 12(1): 110 - 113. 2018.

ISSN: 0973-9467

(c) East Himalayan Society for Spermatophyte Taxonomy

doi:10.26679/Pleione.12.1.2018.110-113

\title{
Eulophia andamanensis Rchb.f. [Orchidaceae: Epidendroideae: Cymbidieae: Eulophiinae] : an addition to the Orchid flora of Mainland India
}

\author{
Khyanjeet Gogoi \\ TOSEHIM, Regional Orchids Germplasm Conservation \& Propagation Centre (Assam Circle), \\ Daisa Bordoloi Nagar, Talap, Tinsukia 786 156, Assam, India \\ E-mail:khyanjeetgogoi@gmail.com
}

[Received 25.04.2018; Revised \& accepted 18.06.2016; Published 30.06.2018]

\begin{abstract}
Eulophia andamanensis Rchb.f. of Orchidaceae has been added to the orchid flora of Mainland India. A detailed description, illustration with photographs have been provided in this article.
\end{abstract}

Key words: Eulophia andamanensis, Manas National Park, new record, terrestrial orchid.

\section{INTRODUCTION}

During a field trip to the forested area of Manas National Park in the Chirang district of Assam on 12 October, 2016, the author collected an unidentified terrestrial orchid in its vegetative condition. The orchid was planted at the Regional Orchids Germplasm Conservation and Propagation Centre (Assam Circle), Assam and flowered under observation in April, 2018. On the basis of available literature (King \& Pantling 1898; Pradhan 1979; Chowdhery 1998; Pearce \& Cribb 2002; Lucksom 2007; Rao 2010; Gogoi 2018) and critical examination of the flowers, it was identified as Eulophia andamanensis Rchb.f. that has earlier been known from Nicobar Islands, Andaman Islands (type), Myanmar, Laos, Vietnam, Cambodia, Peninsular Malaysia and Sumatra (Pedersen et al. 2014) but was never before reported from the Indian mainland. Hence, a detailed description, illustration, information on habitat and distribution has been provided in the present manuscript. The voucher specimen has been deposited at the Herbarium of the Department of Life Science, Dibrugarh University and Herbarium of The Orchid Society of Eastern Himalaya (TOSEHIM), Regional Orchid Germplasm Conservation and Propagation Centre (Assam Circle), Assam.

The genus Eulophia was first described by John Lindley in 1821. The name "Eulophia" was derived from the Greek words "eu" (well) and "lophos" (plume), referring to the crested ridges of the lip in most species (Pridgeon et al. 2009). They are usually terrestrial or ground orchids, although some are epiphytes, and rarely, lithophytes (Chen et al. 2009).

About 200 species distributed tropical and subtropical regions, most diverse in Africa, but also widespread from Madagascar and the Mascarene Islands to $\mathrm{C}$ and tropical Asia, the SW Pacific islands, and N and NW Australia (Chen et al. 2009). According to Misra (2007) 32 species in India (9 species endemic viz. Eulophia campbellii Prain, E. emilianae C.J. Saldanha, E. kamarupa Sud. Chowdhury, E. mannii (Rchb.f.) Hook.f., E. nicobarica N.P. Balakar. \& N.G. Nair, E. obtusa (Lindl.) Hook.f., E. ochreata Lindl., E. pratensis Lindl. and E. santapaui Panigrahi \& Kataki). In Assam the genus was represented so far by 9 species (Gogoi 2018) 

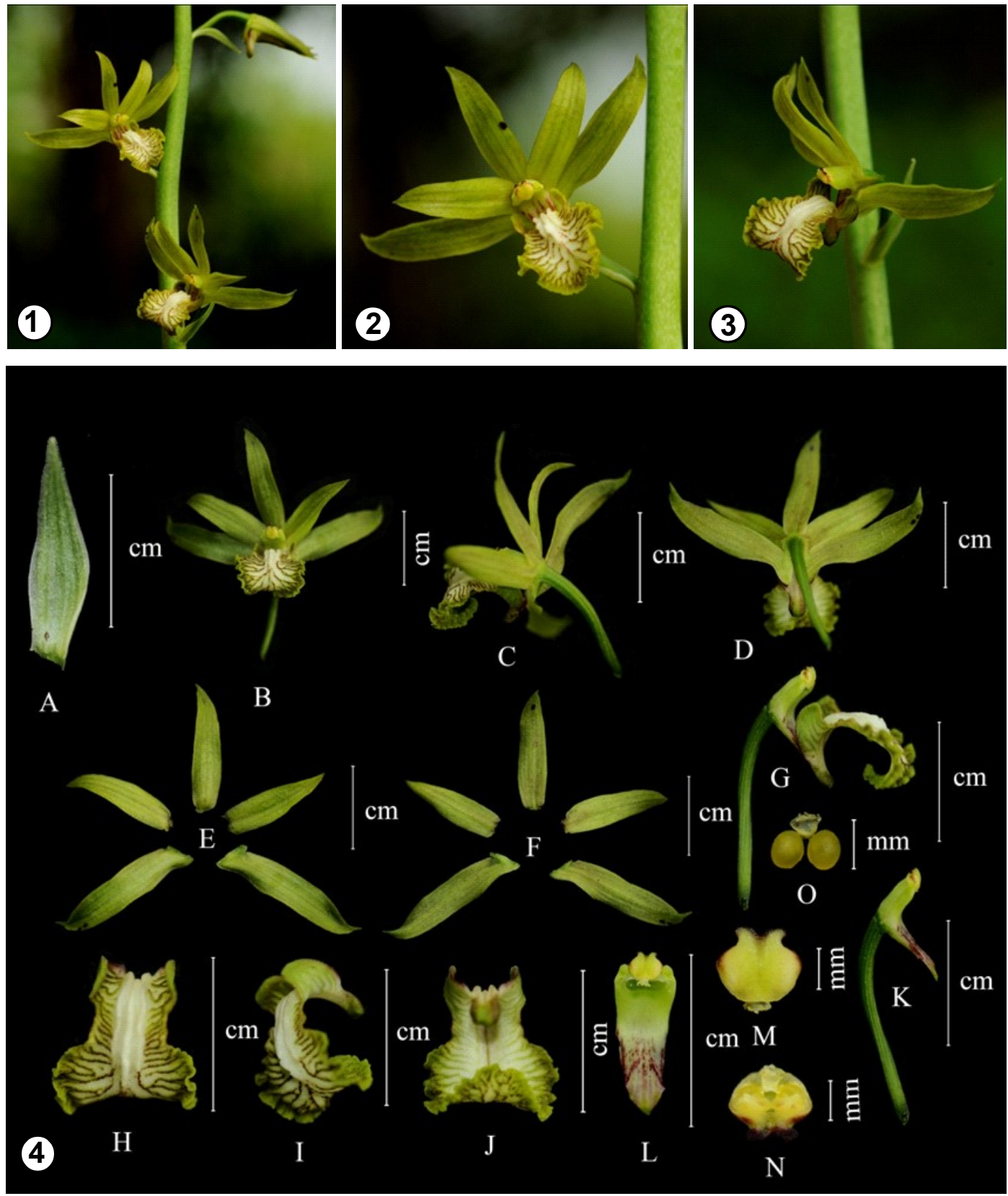

PLATE - I: Eulophia andamanensis Rchb.f. : Figs. 1 - 3. Different views of flowers; Fig. 4. A. floral bract; B, C \& D. flower; E \& F. perigone, ventral and dorsal views; G. lip with ovary and column; H, I \& J. lip; K. pedicel, ovary and column; L. column; M, N. ventral and dorsal views of anther cap with pollinarium; $\mathbf{O}$. pollinarium.

viz. Eulophia bicallosa (D. Don) P.F. Hunt \& Summerh., E. dabia (D. Don) Hochr., E. graminea Lindl., E. herbacea Lindl., E. kamarupa Sud. Chowdhury, E. mannii (Rchb. f.) Hook. f., E. pauciflora Guillaumin, E. spectabilis (Dennst.) Suresh and E. zollingeri (Rchb. f.) J.J. Sm. In the present paper, Eulophia andamanensis Rchb.f. is reported for the first time from Mainland India and the orchid flora from Assam, hence, now comprises of ten species of Eulophia. 
Eulophia andamanensis Rchb.f., Flora 55: 276. 1872; Hook.f., Fl. Brit. India 6: 8. 1890; Pradhan, Indian Orchids II, 460. 1979; Kumar \& Manilal, Cat. Ind. Orch., 74. 1994; Misra, Orch. India, 299. 2007; Pedersen, Henrik A.E. et al. Flora of Thailand, 12, 2: 502. 2014; Karthigeyan, Jayanthi, Sumathi \& Jalal, Richardiana 15: 47. 2014. Graphorkis andamanensis (Rchb.f.) Kuntze, Revis. Gen. P1. 2: 662. 1891. Cyrtopera andamanensis (Rchb.f.) Rolfe, Gard. Chron., ser. 3, 18: 581. 1895. Eulophia keithii Ridl., J. Linn. Soc., Bot. 32: 333. 1896. E. poilanei Gagnep., Bull. Mus. Natl. Hist. Nat., sér. 2, 3: 683. 1931. [PLATE - I]

Type: [K000078337 (K) from Malaysia; K000078335 (K) from Singapore]

Plants pseudobulbous. Pseudobulbs (corms) obliquely conical, fusiform, 2.5-8.0 $\times 1.3-2.9$ $\mathrm{cm}$. Leaves 3-7, linear to narrowly lanceolate, acute to acuminate, 3-40 $\times 0.5-1.5 \mathrm{~cm}$. Inflorescence racemose, $24-40 \mathrm{~cm}, 5$ - to many-flowered; peduncle green, 8-5 cm long; floral bracts shorter than ovary. Flowers suberect to spreading, opening widely, mainly green to brownish green; lip white with green margins and maroon veins. Sepals acute to acuminate, sometimes mucronate; dorsal sepal linear to lanceolate, $1.1-2 \times 0.1 .2-0.4 \mathrm{~cm}$; lateral sepals obliquely linear to lanceolate, $1.2-2.0 \times 0.1-0.4 \mathrm{~cm}$. Petals obliquely linear-lanceolate, acute to acuminate, sometimes mucronate, $0.9-2.0 \times 0.2-0.3 \mathrm{~cm}$, glabrous. Lip 3-lobed, $0.8-1.2 \times$ $0.5-1.2 \mathrm{~cm}$ when flattened, widest across mid-lobe, spurred at base, glabrous on the ventral surface; mid-lobe obovate to elliptic or suborbicular, rounded, margins undulate; ornaments of 3 entire to somewhat warty keels starting from the labellum base and terminating on the mid-lobe; lateral keels shorter than the median; spur subclavate, straight to slightly incurved, 0.3-0.4 cm long. Column 0.3-0.5 cm long; column foot subequal to column proper, not forming a spur. Ovary with pedicel $1.0-2.4 \mathrm{~cm}$ long. Capsule pendent $2.5-2.9 \times 1.0-1.4 \mathrm{~cm}$.

Specimen Examined: Manas National Park, Assam, Gogoi 00766, dated 12.10.2016; Dibrugarh University Herbarium.

Distribution in India: Nicobar Islands, Andaman Islands and Manas National Park (Assam and Bhutan border) in the Chirang district of Assam.

General Distribution: India [Nicobar Islands, Andaman Islands (type), Assam], Myanmar, Laos, Vietnam, Cambodia, Peninsular Malaysia, Sumatra.

Habitat: Terrestrial orchid seen growing in a mixed deciduous forest.

Flowering: March - May.

\section{LITERATURE CITED}

Chen, X.; Liu, Z.; Zhu, G.; Lang, K.; Ji, Z.; Luo, Y.; Jin, X.; Cribb, P.J.; Wood, J.J.; Gale, S.W.; Ormerod, P.; Vermeulen, J.J.; Wood, H.P.; Clayton, D. \& Bell, A. 2009. Orchidaceae, in: Wu, Z.; Raven, P.H. \& Hong, D. (eds), Flora of China. Vol. 25. Science Press, Beijing; Missouri Botanical Garden Press, St. Louis, USA

Chowdhery, H.J., 1998. Orchid Flora of Arunachal Pradesh. Bishen Singh Mahendra Pal Singh, Dehra Dun, India.

Gogoi, K. 2018. Wild Orchids of Assam - A Pictorial Guide. Assam State Biodiversity Board, Guwahati, Assam.

King, G. \& Pantling, R. 1898. The orchids of the Sikkim Himalayas. Annals of the Royal Botanical Garden, Calcutta 8: 1 - 342.

Lucksom, S.Z., 2007. The Orchids of Sikkim and North East Himalaya. Development Area, Jiwan Thing Marg, Gangtok, East Sikkim, India. 
Misra, S. 2007. Orchids of India. Bishen Singh Mahendra Pal Singh, Dehra Dun, India.

Pearce, N.R. \& Cribb, P.J. 2002. Orchids of Bhutan: Flora of Bhutan. Vol. 3, No. 3. Royal Botanical Garden, Edinburg.

Pedersen, H.A.E.; Kurzweil, H.; Suddee, S.; Vogel, Ed F.; Cribb, P. J.; Chantanaorrapint, S.; Watthana, S.; Gale, S.W.; Seelanan, T. \& Suwanphakdee, C. 2014. Flora of Thailand, Vol-12, 2: Prachachon co. ltd., Thailand.

Pradhan, U.C. 1979. Indian Orchids Guide to Identificationand Culture. Vol.- II. Thomson Prass, Faridabad, India.

Pridgeon, A.M., P.J. Cribb, M.W. Chase \& F.N. Rasmussen 2009. Genera Orchidacearum, Vol. 5: Epidendroideae (Part 2). Oxford University Press, 584 pp.

Rao, A.N. 2010. Orchid flora of Arunachal Pradesh - an update. Bull. Arunachal For. Res. 26 (1\&2): $82-110$. 